\title{
THE CREATION OF A VIRTUAL MUSEUM \\ OF SLAVIC CULTURES AS AN ESSENTIAL TASK FOR MODERN SLAVISTICS ${ }^{1}$
}

\begin{abstract}
:
The article highlights the need to create a virtual Museum of Slavic Cultures. In our time of rapid digitalization of various spheres of life, this need seems to be obvious. The Museum's materials concerning cultures of Eastern and Southern Slavs from ancient times to the present day are to be posted on the websites of the Bulgarian Academy of Sciences and Ghent University not only in Russian, but also in English as it is the most common language in the world, with about 1,5 bln speakers. This will allow for a breakthrough in the dissemination of knowledge about Slavic cultures in non-Slavic environments. The Museum's collections will not duplicate the materials available in numerous specialized encyclopedias, handbooks and on Wikipedia. Articles for the Museum will be written by the finest specialists working today, who will be able to build an accurate cultural landscape of the Slavic world, without overloading the visitors with secondary and unnecessary facts. The author proposes as optimal a three-part structure for the Museum's articles, which, accompanied by visual materials, will be able to satisfy a wide variety of interests and tastes of visitors to the future Museum.
\end{abstract}

\section{Keywords:}

Virtual Museum of Slavic Cultures, Dissemination of knowledge about Slavic cultures in the world, format of museum articles.

АННОТАЦИЯ: И.И. КАЛИГАНОВ. «СОЗДАНИЕ ВИРТУАЛЬНОГО МУЗЕЯ СЛАВЯНСКИХ КУЛЬТУР КАК НАСУЩНАЯ ЗАДАЧА СОВРЕМЕННОЙ СЛАВИСТИКИ».

В статье подчеркивается необходимость создания виртуального Музея Славянских Культур - задача, которая в наше время стремительной цифровизации различных сфер жизни, представляется самоочевидной. Материалы из него о культурах южных и восточных славян от древности до наших дней предполагается разместить на вебсайтах Болгарской Академии наук и Гентского университета не только на русском языке, но и на английском - самом распространенном языке в мире, которым в той или иной мере владеют около 1,5 млрд человек. Последнее позволит осуществить прорыв в распространении знаний о славянских культурах в неславянской среде. Экспозиция подобного музея не будет дублировать материалы, имеющиеся в многочисленных специализированных энциклопедиях, справочниках и Википедии. Статьи для Музея будут созданы лучшими специалистами, способными выстроить точный культурный ландшафт Славянского мира, не загружая сознание посетителей второстепенными и в целом ненужными им фактами. Автор предлагает оптимальную трехчастную структуру музейных статей, которые, в сопровождении визуальных материалов, будут способны удовлетворять самые различные интересы и вкусы посетителей создаваемого Музея.

\section{Ключевые слова:}

Виртуальный Музей Славянских Культур, распространение знаний о славянских культурах в мире, формат музейных статей.

\footnotetext{
1 The work was carried out with the financial support of the RFBR (grant № 18-512-76004).
} 
The process of digitalization is gaining momentum in many areas of our 1 lives today. Various documents such as accounts, design drawings, library catalogs, and academic publications are transformed into digital formats. Young people are increasingly favouring electronic media over paper media. Subway passengers now read electronic books on tablets and iPads, rather than traditional printed books. Older people at home read famous novels downloaded from the Internet, rather than physical copies bought in a bookstore.

The articles in the book you now hold in your hands are also a part of this process of digitalization. They are connected with the international tripartite (Belgium-Bulgaria-Russia) project "Diversity and Interaction of cultures of the Southern and Eastern Slavs from the 11th to the 20th century", which won the European Union ERA NET RUS Plus competition. They exist not only in print but also in electronic form and are posted in Bulgarian, Russian and English on the websites of the Bulgarian Academy of Sciences (see https://sesdiva.eu) and the Ghent University in Belgium. Plans for the virtual museum of written cultures of the Southern and Eastern Slavs were developed at the meeting of project coordinators (General coordinator, Bulgarian prof. Anissava L. Miltenova, Belgian coordinator, prof. Dieter Stern and Russian coordinator, prof. Igor I. Kaliganov) at the Ghent University in the summer of 2018. They decided to create ten "rooms" in the Museum as follows: 1) the oldest and most famous pillars of literature and writing of the Southern and Eastern Slavs; 2) migration of books, texts and ideas: literary and cultural exchange between Slavic South and East; 3) centers of cultural communication during the Middle Ages and the early period of the modern era (Athos, Kiev, Moscow, Odessa, Monastery of Rila, etc.); 4) popular saints, authors and works; 5) collections of manuscripts and books: their collectors and creators of libraries; 6) the origins of and the dissemination of individual readings in Slavia Orthodoxa; 7) Russian emigration in the Balkans; 8) immigrant literature and culture through the ages; 9) national revival of the Slavs (Balkan writers of the 18th and19th century about Russia); 10) writers and scholars of the 19th and 20th centuries ${ }^{2}$.

The format of future museum articles was also approved at the same meeting. It was decided that they should not exceed four to five standard pages, including a bibliography, and should be accompanied by five to ten illustrations. Unfortunately the concrete work on the implementation of this project ran into some real difficulties, which related both to the configuration of the conceived virtual museum and to the preparations of its articles. The total number of participants from three countries was only 23, and they were certainly unable to fully fill all ten "rooms" of the Museum in two years (the term of the project). The approved maximum article length was another Procrustean bed. The participants of the project found themselves at a crossroads: on the one hand,

${ }^{2}$ Kaliganov I., Miltenova A. Virtualen muzej za kulturite na južnite i zapadnite slavjani prez XI-XX century // Starobalgarska literatura. 59. Sofia, 2019. P. 262-67. 
they wanted to write in the usual academic language, using footnotes and academic terminology in the articles, and on the other hand, they were aware that the Museum should not be aimed at just a few narrow specialists, intimidating many visitors with excessive academic details or unnecessary facts. In any case, the maximum permissible article length adopted at the Ghent meeting was simply unrealistic in this context.

The first book of "Materials" (it was published in Russian five months before) included over 60 articles by the Russian project participants (all of them are scholars from the Institute of Slavic Studies of the Russian Academy of Sciences), which reflect various stages of development of the most optimal format for the Museum's publications. It contains both purely academic works with numerous footnotes and solid bibliography of academic literature (for example, articles by Marina M. Frolova, Ksenia V. Melchakova and some by Yury A. Labyntsev, which illustrate unsuccessful attempts to transition to a more acceptable museum format) and academic publications which are in line with gradually established new requirements. The second book of "Materials" was published in English. All the authors sought to comply with the format adopted at the Ghent meeting of coordinators. There were no foot-notes in the works, the bibliography was very short, and as a consequence of reducing article length by these means it became possible to expend the main introductory part and to strengthen the hermeneutical principle. These articles by Russian project participants will be published on the websites of the Bulgarian Academy of Sciences and the Ghent University in Russian and English. The process of preparing the articles benefited from the unique resources of the Institute of Slavic Studies of the Russian Academy of Sciences (RAS), which brings together specialists from all countries of the Slavic South and East. The reader will find in this book and on the websites mentioned above articles by our scholars about the cultures of Belarus', Bulgaria, Bosnia and Herzegovina, Croatia, North Macedonia, Montenegro, Russia, Serbia, Slovenia and Ukraine.

As I worked on the project, I quickly developed the conviction that work in this area should continue after the end of the project's term. The outcome of the project, in my opinion, should become the first stone laid in the foundation of the virtual Museum of Slavic Cultures (VMSC), which concerns not only the Slavic South and East, but also the West, and its focus should not be limited only to written cultures ${ }^{3}$. The cover of this book features an image of

3 This consideration was expressed by me in a report at the conference in October 2018. See: Kaliganov I.I. Mysli o grjadyshchem Muzee Slavjanskih Kul'tur kak nasushchnoj zadache sovremennoi slavistiki" / "Thoughts on the forthcoming Museum of Slavic Cultures as an essentual task of modern Slavistics" // Tezisy dokladov podgotovitel'noi nauchno-prakticheskoi konferentsii "Raznoobrazie i vzaimodeistvie pis'mennyh kul'tur juzsnyh i vostochnyh slavjan v XI-XX vv." V ramkah mezsdynarodnogo tryohstoronnego projekta Bel'giaBolgaria-Rossia (ERA) / Theses of reports of the preparatory theoretical and practical conference "Diversity and interaction of written cultures of Southern and Eastern Slavs in the 11th -20 th century." within the framework of the international tripartite project Belgium-Bulgaria-Russia (ERAa). October 23, 2018. Moscow, 2018. P. 3-5. 
a slice of a "tree" representing Slavic cultures, which reflects a somewhat naive, romantic conception of 19th century Slavophiles about the unity of Slavic cultures throughout their centuries-old development. In fact, this development was much more complex and cannot be reduced to a simple increase in the number of "annual rings" and the gradual growth of the tree trunk outwards. Here, it would be more appropriate to talk about a multi-core spiral "cable" with both increasing and decreasing cores in cross section, which have the ability to weave together, can mutually merge or branch, can multiply and reduce their own number, as well as the diameter of their space-time turns.

I used the image of the "tree" slice solely to illustrate the general configuration of the future virtual Museum of Slavic Cultures and to highlight its main components. As we move from the center outwards, the following materials are seen to be optimal:

A) Proto-Slavic language, ancient Slavic mythology and other sections of ancient Slavic folklore;

B) Pillars of writing and literature; regional transformations of the ProtoSlavic language in the South, East and West of the Slavic world up to the present day;

C) Folk culture;

D) Domestic, cult and secular architecture;

E) Sculpture;

F) Religious and secular painting;

G) Theatre;

H) Cinema;

I) Music.

Inclusion the VMSC of sections on the political history of Slavic states seems inappropriate to me. In the social sciences system, this discipline is one of the most changeable and opportunistic. Every 30-50 years, at the request of power structures, political history begins to be rewritten in accordance with changes in geopolitical orientations. Therefore, it is more reasonable to exclude materials of this kind in the VMSC: they would become a time-bomb, which will sooner or later demonstrate its destructive force. The contours of political history can only be made in dotted lines to denote the volatile configuration of common cultural zones, the boundaries of which do not usually coincide with the boundaries of political zones.

National and institutional factors may pose a significant risk in the construction of the VMSC. The creators's over-patriotic desire to maximise the representation of their "national" materials in the Museum could lead to a heavy-handed and therefore poor resource. It could lead to the inclusion of museum articles and "exhibits" belonging to more minor stages of cultural development, which have neither originality nor special significance against the background of the world cultural landscape. The same concern applies to the institutional factor: 
usually after many years of academic research, scholars are so deeply converged with their field of specialization (in our case, culture) that it seems to them more important than any others. This can lead to an overvaluation by researchers of the cultural phenomena they are engaged in and the desire to provide them with a place in the Museum. The Louvre would not exihibits artifacts suitable for a museum of local history. Similarly, for the exhibitions it is necessary to select only the most precious, valuable and worthy topics, otherwise English-speaking visitors to the museum may form an incorrect opinion about the relatively low level of development of Slavic cultures, and, as such, conclude that they are secondary to Western European cultures.

The filter here is intended to be the word-list, drawn up on the basis of reasonable quotas. These should be established taking into account the size of each Slavic country and the size of their contribution to a particular area of Slavic culture. It is possible, for example, to ask specialists to select 150 names of the best Russian writers from the 11th to the 20th century, 120 Polish, 80 Czech, 50 Serbian, 40 Croatian, etc. Of course, these figures are selected at random for the purposes of illustration and can be further adjusted up or down, as required. The size of the contribution by a group of Slavic peoples to the general Slavic cultural treasury was not always directly proportional to their numbers, and in the course of history their share in it usually varied and was not equal in all areas of national culture. The same is true of architecture, painting, sculpture, music, film art and other cultural activities of Slavic peoples.

As I worked on the creation of a virtual museum of written Slavic cultures of the Southern- and Eastern Slavs from the 11th to the 20th century, I gradually developed an idea of the most optimal format for articles of the future of the $\mathrm{VMSC}^{4}$. In my opinion, their average volume should be at least seven to ten pages with a maximum of 20,000 characters. And their structure should not be twopart, but three-part.

The first, as already mentioned, should be created in a hermeneutical way. Throughout work, it is necessary to insure that the unprepared visitor is not put off by the excessive amount of unnecessary academic facts, and to explain in simple language the essence of the described phenomenon of culture and its uniqueness (whether it is the first national poet, the father of war reporting, the most ancient dated manuscript of the East Slavs, the first national novelist, etc.). The descriptions of articles in the VMSC, in my opinion, should not follow the practice of encyclopedias and specialist handbooks, which give concise names of monuments or personal names of writers, and then in the main text begin a more detailed story about them. It is probably better to immediately inform the reader about the essence of article, i.e. to observe a kind of "etiquette" typi-

${ }^{4}$ It was outlined by me in my report at the conference already mentioned. See: Kaliganov II. "Zametki ob optimal'nom 'muzeinom' formate statei dlja virtual'nogo Muzeja Slavjanskih Kyl'tur" / "Notes on the optimal "museum" format of writing articles for the virtual Museum of Slavic Cultures..." P. 6-8. 
cal to authors of the 18th century, who would courteously inform their reader about their topic from the start. In order to avoid making the title too long, it can be followed by three to five sentences which serve the purpose described. Even if the reader does not read the article further, he will remember the fact that Vas. I. Nemirovich-Danchenko, for example, is the father of Russian military journalism, and A.D. Chertkov was the founder of the first free public library in Moscow. Thus, even the names of the articles of the VMSC will play the role of a concise dictionary of Slavic cultures for adults.

The first part of the article should also describe very accurately and succinctly the essence of the phenomenon of Slavic culture with which the article is concerned. This task can be solved only by highly qualified specialists, who have deep knowledge not only of the subject matter of the narrative, but also have a clear idea of similar phenomena in the development of Slavic cultures and can build a real cultural scale of proper proportions. The ideal persons here are academic scholars: primarily, those of them who are gifted writers. After all, it is no secret that many academic works by serious scholars are written in unwieldy complicated language which repels those who try to read them. In preparing the first hermeneutical part, it is impossible to exclude the involvement of external stylists who can turn difficult texts into clear, understandable, readable ones. Footnotes to academic works in the hermeneutical part are not desirable: they are unnecessary here and only distract the visitor from the hermeneutical essence of the cultural phenomenon which is being presented.

The second part of the article will be initially hidden from the reader: it will be accessible through a link with the lable "Historiography". It will be two to three pages long and purely academic in nature. It is intended for those scholars who will want to familiarize themselves with the history of studying this cultural phenomenon in detail. Here, in order to save space, it is possible to use a dry academic style, abbreviations, and use numerous references to academic literature. These are done in the style commonly used by linguists: the text in parentheses gives the name of the academics, the year of publication of the academic work and the referenced page numbers.

The third part, entitled "Bibliography", which will also be accessed through a link, is intended for both a wide range of visitors to the VMSC and scholars. Here you will be able to find a short list of academic and popular literature on the issue, as well as a list and full titles of the specialist's works, to which references were made in the "Historiography" section. The size of this part should not exceed one standard page of text typed with size 14 font.

Articles will be accompanied by a "Gallery", which will contain five to ten illustrations related to the most important moments in the narratives.

My proposed format of museum articles allows us to harmonize the distribution of the included materials. It is hoped that this will lead to the "display" of the VMSC becoming popular and accessible for a wide range of visitors. It will be useful to both non-specialists and scholars. This is especially true of the hermeneu- 
tical part of the museum articles in their English-language version, which allows the VMSC to find its niche among specialized printed directories and helps it avoid incorrect comparison with Wikipedia. If we consider that 1.5 billion people in the world understand English, it will become clear that creation of VMSC is capable of leading to the real breakthrough in dissemination of knowledge about the cultures of the Slavic peoples and their historical development.

$* * *$

In preparing this book, I have tried to ensure that it meets high English language standards as fully as possible. I offer my deep gratitude to its first proofreaders, who, like skilled pilots, helped to steer my Russo-English sailboat to the wide ocean expanses of the English language. This task was taken on with honor by Susannah Westen from the United States and John Harwood and Maria Groves from the United Kingdom 5 .

This book is the first edition in English published by the Institute of Slavic Studies of the RAS. And, I hope, not the last. Sincerely loving our native "great" and "mighty" (academic M.V. Lomonosov) Russian language, we should be aware of the fact that in terms of its prevalence it occupies only a modest eighth / ninth place in the world, sharing it with Portuguese. Further, its international usage continues to decline. Unfortunately, numerous academic works published by the Institute of Slavic Studies of the RAS in the Western world become known mainly to rare specialists who know Russian. Articles published in English-language periodicals by Institute scholars can become "lost" in them and are not able to give readers a complete picture of the scope of the academic research conducted at the Institute, nor of its academic direction in the area of Slavistics, nor of the successes achieved in its various fields.

It seems to me that it is long overdue for the Institute to publish a book in English every two years entitled "The Slavic World: Diversity of History and Culture. Selected works by scholars at the Institute of Slavic Studies of the RAS for $202 X-202 X$ years". It will give a wide English-speaking audience insight into the Institute of Slavic Studies and also help to counteract attempts to rewrite European and World history - attempts, which could lead to the establishment of a global hegemony of particular countries and peoples.

Translated by the author

5 I also want to gratitude my son Yaroslav Kaliganov, Maria Harwood and Ksenia Melchakova for their reliable help. 
$* * *$

При подготовке этой книги я старался добиться максимального ее соответствия английским языковым нормам. Выражаю свою глубокую признательность ее первым читателям-корректорам, которые, подобно искусным лоцманам, помогли вывести мой русско-английский парусник на широкие океанические просторы английского языка. Эту роль с честью сыграли Сюзанна Уэстен (США) и Джон Харвуд с Марией Гроувз из Соединенного Королевства 6 .

Данная книга является первым изданием, выпущенным Институтом славяноведения РАН на английском языке. И, как я надеюсь, не последним. При всей нашей искренней любви к родному «великому» и «могучему» (М.В. Ломоносов) русскому языку следует отдавать себе отчет в том, что по своей распространенности он занимает лишь скромное восьмое-девятое место в мире, деля его с языком португальским. При этом его международное использование продолжает сокращаться. К сожалению, выпускаемые Институтом славяноведения РАН многочисленные научные труды в западном мире становятся известны главным образом редким, знающим русский язык специалистам. А публикующиеся в англоязычной периодике статьи институтских ученых «теряются» в ней и не способны дать читателям целостное представление ни о размахе ведущихся в Институте научных славистических исследований, ни о разрабатывающихся в нем научных направлениях славистики, ни о достигнутых им успехах в самых различных ее областях.

Мне кажется, давно уже назрела необходимость публикации Институтом раз в два года на английском языке сборника «Славянский мир: разнообразие Истории и Культуры. Избранные труды ученых Института славяноведения РАН за 202X-202Х гг.. Это позволит широкой англоязычной аудитории иметь ясное представление о научном лице Институте славяноведения РАН и будет способствовать более действенному противостоянию попыткам переписать европейскую и мировую историю ради утверждения гегемонии на земле отдельных стран и народов.

Игорь Калиганов

6 я также хочу поблагодарить моего сына Ярослава Калиганова, Марию Харвуд и Ксению Мельчакову за их безотказную помощь. 
